\title{
The Many FaCes of OBJeCtivity ${ }^{1}$
}

\author{
LOS MÚLTIPLES ROSTROS DE LA OBJECTIVIDAD
}

\section{David Macarthur}

\begin{abstract}
In this paper I present a positive progressive picture of Putnam's philosophy. According to this way of seeing things, Putnam is a normative cartographer of our linguistic practices who has over time refined his understanding of the concepts of truth and verification and their complex relationship from discourse to discourse. Looked at in this way Putnam is primarily a philosopher of objective normativity, who explores the various conceptions of objectivity with which we operate as well as resisting the excesses of both metaphysics and skepticism which do violence to our ordinary and scientific practices. However, Putnam sees himself as a philosopher of 'reality' focused on "the realism issue", a metaphysically inflationary way of thinking that, I argue, stands in the way of his deepest insights.
\end{abstract}

KEYWORDS: realism, antirealism, Metaphysical Realism, metaphysical realism (uncapitalized), internal realism, common sense realism, objectivity, conceptual normativity, common sense, metaphysics, skepticism, quietism.

\section{RESUMEN}

En este artículo, presento una imagen positiva y progresiva de la filosodfía de Putnam. De acuerdo con este enfoque, Putnam es un cartógrafo normativo de nuestras prácticas lingüísticas que, a lo largo del tiempo, ha refinado su comprensión de los conceptos de verdad y verificación y sus relaciones complejas de un discurso a otro. Así contemplado, Putnam es principalmente un filósofo de la normatividad objetiva que explora las diversas concepciones de la objetividad con las que operamos, además de resistir los excesos de la metafísica y el escepticismo que estropean nuestras prácticas normales y científicas. No obstante, Putnam se ve a sí mismo como un filósofo de la "realidad" que se centra en el "problema del realismo", una modo metafísicamente inflacionista de pensar que, defiendo, obstaculiza sus ideas más profundas.

${ }^{1}$ I'd like to thank Gary Ebbs for comments on a draft of this paper. 
PALABRAS CLAVE: realismo, antirrealismo, Realismo Metafísico, realismo metafísico (sin mayúsculas); realismo interno; realismo de sentido común; objetividad; normatividad conceptual; sentido común; metafísica; escepticismo; quietismo.

"different sorts of judgments possess different sorts of objectivity."

Putnam, (2002b, 6).

"the fact that the difficulties are in a sense the same does not mean that they do not require special treatment"

Putnam (2012, 342).

Leaving aside scientific realism, which specifically concerns the existence of the unobservables posited by successful science (in opposition to, say, instrumentalism), I want to focus upon the shift in Putnam's general semantic realist allegiances: from Metaphysical Realism (capitalized, for a reason I shall explain below) to "internal realism" (which, despite the label is a form of antirealism); and from internal realism to common sense (or natural or pragmatic) realism. Henceforth when I use the terms "realism" and "antirealism" I intend to refer to semantic views about the relation between truth and verification (or rational assertibility). ${ }^{2}$

Putnam's changes in realist allegiance can seem mysterious for several reasons. For one thing both Metaphysical Realism and internal realism are, or seem to be, substantial philosophical positions; for example, the first accepts that there is one true and complete description of things, whereas the second denies that. Yet Putnam has cryptically remarked that "commonsense realism by itself isn't a metaphysical position, or even an antimetaphysical position" (1998, 242). Why, then, bother to call common sense realism a form of "realism" - which seems to suggest some commonality (say, of status or explanatory pretension) with his previous realist and antirealist allegiances? Alternatively, if we see what he has called his "long journey from realism back to realism" $(1999,49)$ as nothing more than a movement away from, then back towards, a non-epistemic conception of truth, one might well wonder what the overall gain has been.

There is also the problem that it is relatively easy to find oneself unable to see the forest for the trees when one concentrates on all the detailed argumentation

2 To say that the realism/antirealism issue is semantic is a comment about its formulation. Of course, since these positions involve the concepts of truth and reference they have ontological implications too. 
along the path Putnam has taken including debates surrounding such controversial matters as: the bearing of empirical and conceptual discovery on the a priori; the model theoretic argument and the question of what fixes reference; the doctrine of conceptual relativity in optional theoretical languages; the possibility of reference to the same 'unobservables' in physics despite errors or change in physical theor $y^{3}$; the meaning of natural kind terms; overcoming of the fact/value dualism; and direct realism in the philosophy of perception.

The approach I favour aims to find a progressive story of accumulating insight. Before I explain the approach I want to enter an important qualification about Putnam's use of the term "realism"; and it will help us orient ourselves if we briefly set aside an initially plausible but, I believe, relatively fruitless conception of what Putnam is up to.

Firstly, the term "realism" might be thought to concern, first and foremost, matters of Ontology, especially the attempt to articulate some notion of a mindindependent world. It is worth noting, then, that throughout all these periods, including the internal realist period when Putnam notoriously said that "the mind and world make up the mind and the world" (1981, xi), Putnam always accepted that the reality of, say, stars, glaciers and electrons was causally independent of minds. And he always accepted a thesis of logical independence too: the existence of stars, glaciers and electrons neither entails, nor is entailed by, the existence of minds, whether considered individually or collectively. That is, the internal realist is still a realist regarding these sorts of entities (or was intended to be such) - since Putnam allowed that verification of such facts need not be humanly possible even if he also counted, in Kantian fashion, as a kind of anti-realist in virtue of identifying truth with a form of idealized verification. Putnam has long argued that if one does not mean either causal or logical independence then it is unclear what "mind-independent" is supposed to mean in realist-antirealist debates (e.g., 1992, 355). Consequently, the appeal to "mind-independent" reality does not seem capable of sustaining any progressive explanation of Putnam's changes in realist allegiances. For present purposes, then, I shall set this issue aside - though it will be necessary to return to it later.

\footnotetext{
${ }^{3}$ For instance, in 1911 Niels Bohr was capable of referring to electrons despite holding an inadequate theory of electrons.

4 Though certain ways of describing mental states do have such implications e.g. perceptual verbs whose use implies success. If "S sees O" it is implied that $\mathrm{O}$ exists. But it is possible to use less committal locutions e.g. in this case, appealing to perceptual experience.
} 
Secondly, one might think that the shifts in realist allegiance we have canvassed are a matter of Putnam's offering different answers over time to what he has described as the great question of realism, "How does the mind or language hook on to the world?" ${ }^{5}$ But this, too, would be misconceived. Post-1978 Putnam holds that this is not a fully intelligible question since it presupposes a God's eye view from which we are supposed to be able to compare mind and language with the world itself, where mind and language are somehow conceived independently of the world; and the world independently of mind and language. It follows that we cannot appeal to changes in answers to this question to explain Putnam's realist allegiances. Of course, it is true that Putnam has changed his views about the conditions for our referential abilities in different regions of thought but there is no progressive big story to tell about reference as such because Putnam has long been an anti-essentialist about what constitutes referring. ${ }^{6}$

If we are not to understand Putnam's movement from Metaphysical Realism to internal realism to common sense realism in terms of either mind-independent 'objects' or intentionality then how are we to understand it?

In this paper I want to cast light on Putnam's philosophical motivation for these shifts of position by emphasizing two pragmatist themes that are not normally brought to bear on this aspect of his thought. The two closely related themes are: 1) the practical priority of the normative in everyday and scientific discourse over the purely metaphysical matter of Ontology; and 2) the importance of articulating the normative dimension of our practices - which centrally involves articulating the objectivity that these practices institute or make allowance for - from an engaged practitioner's point of view. ${ }^{7}$

${ }^{5}$ For example, Maximillian De Gaynesford (2006) takes the theme of thought's intentional directedness to reality to be the key that unlocks Putnam's thought.

6 Putnam notes "that reference is a 'family resemblance' notion (there being no 'essence' of referring), and that the notion of reference is constantly undergoing extensions..." (Hill (ed.), 1993, 406, fn. 56). See also $(1988,11)$.

7 The present paper can be read as a sympathetic critical response to Gary Ebbs's reconstructive reading of Putnam which is centred on the largely correct thought that "our participation in everyday and scientific linguistic practices subjects our statements to norms that determine what we are talking about, when we agree, and when we disagree. Putnam's project is to clarify our implicit, practice-based understanding of these norms" (1992, 2). 


\section{The Priority of the Normative}

One way to see what goes wrong in approaching the question of realism in terms of radical mind-independence or big " $R$ " (i.e. metaphysical) Representation is that we seem to need a conception of all the 'Objects' there are from a God'seye point of view in order to conduct this sort of inquiry. On this way of seeing things we must start with Ontology - understood as a foundational metaphysics of Being which allegedly tells us what basic kinds of 'objects' collectively constitute the fabric of the world. Then we ask questions about their explanatory status and how the mind hooks onto them. But, for Putnam, philosophy cannot begin with Ontology since, for one thing, it faces insuperable epistemological problems, and, as we will see, the problem of conceptual relativity. It must begin, rather, with a sense of the normative landscape we inhabit from an insider's perspective on our many and various discourses, as he explains:

In place of Ontology (note the capital "O"), I shall be defending what one might call pragmatic pluralism, the recognition that it is no accident that in everyday language we employ many many different kinds of discourses, discourses subject to different standards and possessing different sorts of applications, with different logical and grammatical features, different "language games" in Wittgenstein's sense - no accident because it is an illusion that there could be just one sort of language game which could be sufficient for the description of all of reality! $(2004,21)$

I want to follow the suggestion of this passage and argue that we do most justice to the bulk of Putnam's thought (and, I believe, to its most lasting insights) if we see the changes from one form of realism to another as reflecting a lifelong meditation on, and attempt to articulate, the indispensable objective normative dimension of our actual practices of rational thought and criticism; most especially, our use of the central normative terms "understanding", "truth" and "justification" in one or other domain of discourse. ${ }^{8}$

For the purposes of this paper I want to set aside discussion of "understanding" and concentrate on "truth" and "justification". From this perspective Putnam can be understood to be asking such questions as: What counts as justification in scientific or moral or aesthetic (etc.) discourses? How objective is it? And what is the relation between truth and justification in science, say, or ethics? - where allowance is made for the possibility that different answers will be appropriate in different discourses.

\footnotetext{
8 Putnam has called this a matter of "trying to understand the life we lead with our concepts in each of these distinct areas" $(2012,386)$.
} 
What I would like to argue is that Putnam's realist allegiances are a testament to his progressively insightful attempt to explain the objectivity of our judgments in different regions of discourse: to demonstrate both the reality of the topics of our thought and talk (by way of an account of truth and reference for the discourse) as well as the kind of correctness attaching to judgments about them which may vary as the subject matter and circumstances vary.

\section{Stage-SETTING: The SEARCH FOR A THIRD WAY}

In order to approach the question of what the objectivity of our normative notions comes to for Putnam it is important to do some stage-setting. Let us consider this remark,

On the one hand our understanding of our concepts, and our employment of them in our richly conceptually structured lives, is not a mystery transaction with intangible objects, a transaction with something over and above the objects that make up our bodies and our environments; yet as soon as one tries to take a normative notion like the understanding of a concept or Wittgenstein's notion of the use of a word, and equate that notion with some notion from stimulus-response psychology ("being disposed to make certain responses to certain stimuli"), or a notion from computational psychology, or a notion from the physiology of the brain, then the normativity disappears, and hence the concept itself disappears. $(2012,384)$

This passage concerns the difficulty, in our attempt to understand the objectivity of central normative notions such as truth, justification and understanding - of steering clear of the twin threats of: on the one hand, the hyperbolization of objectivity in metaphysical thinking (e.g. the Platonic or mathematical realist notion of "intangible objects", the Metaphysical Realist's conception of a fixed realm of metaphysically privileged 'Objects'); and, on the other, the denial or denigration of objectivity in skeptical thought (e.g. reductionism of one kind of another, be it behaviourist, physiological or physicalist). The criticism of this oscillation between subliming objectivity (especially tying the notion to an unchanging realm of metaphysically privileged 'Objects' of some sort) and denying objectivity (say through some form of subjectivism or skepticism), is played out again and again in Putnam's writings. For instance, it explain his frequent attacks on the Metaphysical Realists' notion of correspondence truth and a metaphysically guaranteed reference relation as well as his critiques of postmodern nihilism and Rorty's relativistic conception of justification. 
Putnam's achievement here is to show that we do not need to accept the appearance of a forced choice between an inhuman Objectivity (i.e., "the view from nowhere" (Nagel, 1986, 5), "the absolute conception" (Williams, 1985, 139)) and no objectivity at all (which is variously called "nihilism" or "skepticism" or "relativism"). ${ }^{9}$ However, it is easy to misunderstand the alternative way of thinking that Putnam pithily expresses thus, "We have... better and worse versions, and that is objectivity enough" $(1987,77)$. This might just seem to raise the question of objectivity all over again: Better or worse for whom? Better or worse in what respect? Is objectivity a unitary or plural notion? But rather than being problems, such questions point the way towards resolutions.

\section{THE CONCEPT AND CONCEPTIONS OF OBJECTIVITY}

To explain Putnam's thought here it is helpful to employ the Rawlsian distinction between concept and conceptions. ${ }^{10}$ The concept of objectivity, the abstract idea that there are better or worse answers or responses to our questions - which implies that simply thinking that $\mathrm{p}$ does not make it so that $\mathrm{p}$ - is what all conceptions of objectivity share in common. But the abstract concept of objectivity tells us very little unless we know what sense we are to attach to these terms in their application to specific cases. This is precisely the function of conceptions of objectivity. In the history of philosophy there have been many conceptions (or detailed working models) of objectivity to provide the ideas of better and worse with specific content and guide us in to how to apply them. Some important conceptions include: 1) the account of objectivity in terms of objects of one kind or another (e.g. Plato's Forms, the fixed 'Objects' of Metaphysical Realism, physical objects); 2) the Kantian account of objectivity in terms of universal principles or rules of judgment; and 3) the conventionalist account of objectivity in terms of conventions or intersubjective agreements (e.g. the appeal to linguistic conventions).

In Putnam's way of thinking our conceptions of objectivity are plural and everexpanding. We make a profound mistake if we treat any one of them as what objectivity

\footnotetext{
${ }^{9}$ It might be noted in passing that this attests to an important difference between Putnam's and Rorty's versions of neo-pragmatism. Rorty effectively accepts the appearance of the forced choice and opts for the second alternative: no objectivity. But Rorty is not consistent here, sometimes saying he has abandoned objectivity and sometimes saying he has reduced it to solidarity. ${ }_{10}$ This distinction is taken, adapted somewhat, from John Rawls: "Roughly, the concept is the meaning of the term, while a particular conception includes as well the principles required to apply it" (1993, 14, fn. 15).
} 
really is, once and for all, across all discourses. In the case of metaphysical object-based conceptions such as Metaphysical Realism or Platonism, Putnam has long argued for their failure to make full sense (e.g. 2004). How are we supposed to understand, say, the idea that it is the world, not us, that chooses what counts as an 'object'? It follows that not every conception in the history of philosophy is salvageable. Given the wide diversity of discourses, their differing standards and logical properties, any given conception - provided that it is coherent - may well apply to some, but certainly not to all, aspects of our lives. In some cases, as we have seen, that will mean we have to abandon the conception as incoherent (e.g. Metaphysical Realism); in others we have the option of regarding the conception as a metaphor that points towards the application in an imaginative mode (e.g. Platonism about mathematics).

Putnam is trying to get us to see that the core idea of a better or worse that transcends the speaker is presupposed in our many and various practices of inquiry, judgment and adjudicating disputes even if we spell out the notion of better or worse in different ways on different occasions. This is as true in science and mathematics as in such notoriously problematic areas such as ethics and aesthetics where, unlike the former cases, agreement on the facts, together with reasonableness and rational argument do not tend to guarantee agreement about action or evaluation. It is the task for philosophy, on the present reading of Putnam, to show what particular conception of objectivity, hence what conception of rational justification, is appropriate to each of the problematic conceptual difficulties we actually confront in our lives. And a key part of that is determining the standards of justification, and what relation particular conceptions of justification have to the truth.

\section{Normative Insights of Putnam’s Progress}

Adopting this approach it is possible to tell the story of Putnam's realist allegiances as a story of his growing appreciation of the normative fine structure of rational justification and its differing relation to truth in different areas of our lives with words. Let me give a brief summary of some of the highlights of Putnam's progress:

\section{The Movement away from Metaphysical Realism}

We can see two points emerge as key reasons why Putnam moved away from Metaphysical Realism. Firstly, the hyper-objectivist idea that truth is a matter of correspondence with worldly facts that are radically mind-independent does no real explanatory work for there is no (actual, ideal or imagined) position from 
which one could verify that this is so. In other words such a 'correspondence' has no connection to our actual practices of inquiry and judgment whether in ordinary life or the sciences $(1981,72-74)$. And if there is a metaphysically privileged notion of object how are we to tell that our ordinary concept of an object 'carves reality at its joints'? Secondly, Metaphysical Realism implies the conceivability of radical skepticism in at least two senses. Firstly, it is committed to the claim that no matter how well justified our judgments are we might conceivably be in error, perhaps even global error; and since the error concerns facts that are radically mind-independent there may be systematic error that is and remains undetectable from the human perspective for eternity. Secondly, our concepts might be 'wrong' in the sense that they fail to 'fit' with the independent order of things so despite being in ideal epistemic conditions and being blameless from the point of view of epistemic practice we might still go wrong in the deeper sense that we have the 'wrong' concepts. These skeptical possibilities are a consequence of the Metaphysical Realists' denial that there is any conceptual relationship at all between truth and rational justification. For Putnam, that is a serious misstep. For one thing it misses an important insight of the verificationist tradition: namely, that for ordinary empirical concepts like that of tree, dog or chair "there is a conceptual connection between grasping [such] an empirical concept and being able to recognize a perceptually justified application of that concept" $(1995,295)$.

\section{Internal Realism: insights and oversights.}

Internal realism was formulated precisely to avoid this mistake (cf. Putnam, 1978, Part 4). It is designed to allow for a greater sensitivity to the diverse normative outlooks of our various practices. On the internal realist view, truth is defined as idealized rational assertibility where what is rationally assertible is allowed, contingently, to outrun what anyone can in fact rationally assert. Internal realism repairs the Metaphysical Realist's denial of any conceptual relationship between truth and justification yet it is supposed to capture our realist proclivities in making allowance for truths not actually verified and for which there may be no humanly possible verification e.g. truths about things or events beyond our light cone or about the distant past, say, whether a dinosaur was or was not drinking water at certain time and place in the Mesozoic period. In other words the internal realist agrees that the empirical world is mind-independent on a reasonable interpretation of that expression. The ordinary distinction between truth and justification is reconstructed as the distinction between justification according to current evidence and "idealized" (i.e. good enough) justification. 
One important advantage this view has over positing a mysterious correspondence relation is that we can explain truth in terms of whatever counts as sufficiently well justified with regard to the subject matter that is in question. Another advantage is that we need no longer be committed to the Metaphysical Realist dogma that there is one true and complete description of reality. That is, internal realism is compatible with conceptual relativity, the rarefied phenomenon of a conceptual choice between one or other equally well justified (i.e. empirically equivalent) optional language for describing some aspect of reality which leads to incompatible world-views that have different ontological commitments (e.g. treating space-time as a matter of points rather than limits, accepting that there are mereological 'objects'). It is the phenomenon of conceptual relativity that makes allowance for their being more than one true and complete description of reality, which is incompatible with Metaphysical Realism.

Nonetheless, Putnam eventually came to see that the internal realist account of the relation between truth and justification itself failed to do justice to our practices since in some imaginable cases truth does indeed outstrip verification altogether. One of Putnam's examples is the truth-value of the statement, "There are no intelligent extra-terrestrials," a negative existential statement that, supposing it is contingently true - that is, supposing that it is possible that there are intelligent extraterrestrials but there just do not happen to be any - is one that we are unable to verify. This is a result based on what we know of physical theory and the absolute limit constituted by the speed of light, namely, that for any given observer there are regions of space-time that that observer cannot receive causal signals from since they are beyond the observer's light cone.

\section{Common Sense Realism: the articulation of the normative from the practitioner's point of view}

What, then, of the turn to common sense realism? Putnam remarks, ...commonsense realism by itself isn't a metaphysical position, or even an antimetaphysical position... The strategy is not to counterpoise an alternative thesis to the various theses of the traditional epistemologists, be they realist theses or idealist theses or empiricist theses or whatever. It consists rather in, first, taking perfectly seriously our ordinary claims to know about the existence of birds and automobiles and what Austin referred to as "middle-sized dry goods," and our ordinary explanations of how we know those things, and, secondly, in meeting the objection that these ordinary claims simply ignore a philosophical problem by challenging the very intelligibility of the supposed problem. (1998, 242; emphases added) 


\section{And}

let me say that (as opposed to metaphysical realism) commonsense realism always seems to ignore (or beg) the philosophical problem rather than respond to it. $(241$, sic.)

According to these formulations common sense realism is not a substantial philosophical doctrine but, in opposition to that, a Wittgensteinian diagnostic approach which regards philosophical problems as confusions that are only apparently intelligible. The job of the common sense realist, on this construal, is to dismantle the illusion of intelligibility of any philosophy that attempts to undermine the common sense world and, thereby, show that there is no genuine problem of realism or idealism left to answer. It follows that there is no need to offer any theory of common sense reality our grip on which is presupposed in our ability to think and talk whether about birds, cars, people and so on. Looked at like this the task seems disappointingly negative.

It is important, then, that one can extend the trajectory of Putnam's thinking we have been following and see common sense realism as another step in the program of understanding the way that central normative notions such as truth and justification relate to one another in specific regions of discourse - making allowance for a plurality of such relations (and a plurality of forms of rational justification) depending on the discourse in question. This exploratory and particularist approach is borne out by Putnam's being prepared to speak of common sense realism about perception, common sense realism about conception, and about rule-following, number theory, provability, tables and chairs, and empirical science - a list that can obviously be extended.

In Putnam's vision the ordinary world of middle-sized perceptible objects (e.g. buildings, cars, trees, pets, sofas, cups) - the "manifest image" as Sellars famously calls it - is in many ways more basic in epistemological terms than the "scientific image" which, in certain respects, is less certain, more changeable, and more open to reinterpretation. With regard to the manifest image, Putnam is prepared to say that truth and rational assertibility coincide - even if we deny the central thesis of internal realism that the concept of truth can be reduced to that of (good enough) verification. Putnam explains,

what I contend is that, in the case of the great majority of our everyday assertions, assertions about the familiar objects and persons and animals with which we interact, truth and idealized rational acceptability do coincide. The reason that they so often coincide is not, however, that truth means idealized rational acceptability, but that, first, it is built into our picture of the world itself that these statements 
can be verified under good enough conditions (when they are true); and, second, the existence of statements of this kind is a conceptual prerequisite of our being able to understand a language at all. $(1995,299)$

Having a firm grip on the common sense world is a crucial precondition for our capacity to share a language together, to express ourselves in that language and, thereby, to make ourselves understood by others.

But why common sense realism? Putnam's use of the term "common sense" does not indicate a dubious Moorean reliance on so-called "common sense propositions" which supposedly form a repository of certain knowledge held in common by everyone (or at least a majority of people) of sound mind or something along those lines. Common sense, rather, refers to acknowledging the indispensable place in our lives of the ordinary claims about ordinary things made from within our practices. That is what it means to take them seriously. This is not just an intellectual matter but something we have a feeling for, which is why it is a "sense"; and it is "common" partly for the reason that the language that presuppose and articulates it is a social phenomenon. Significantly, it does not require any philosophical foundation or guarantee. In this respect Putnam aligns with Wittgenstein when he wrote "the practice has to speak for itself" $(1972, \$ 139) .{ }^{11}$

The term "common sense" also draws attention to the attempt to display our understanding of the normativity of the relevant concepts from the practitioner's (or agent's) point of view, as opposed to an external scientific point of view (e.g., the anthropological approach of Huw Price's subject naturalism (Price, 2011), or Paul Horwich's theory of language use (Horwich, 2005)). Arguably, the conceptual or rational normativity manifested in language use becomes invisible from the point of view of the strongly objectifying stance of the scientist. ${ }^{12}$

Let us briefly consider common sense realism about ethics. Ethical truths do not depend on metaphysics, say, a special non-natural realm of distinctively ethical objects or properties as G. E. Moore intuitionism supposed. Justification here is complex and multivalent: it can involve reasoning about a matter in the right way; imaginatively sharing a perspective on the world; or perhaps modelling oneself on

\footnotetext{
11 Also, for Putnam, common sense is not sacrosanct in the way that Moore or ordinary language philosophers supposed. Putnam sees his job as that of constructing what he likes to call "mild rational reconstructions" of our practices as part of his attempt to make best sense of them.

12 I have argued for this claim at length in Macarthur (2014).
} 
an exemplary person (e.g. Ghandi) ${ }^{13}$. Also, unlike mathematical or scientific truths, which can outrun what we have epistemic access to, such transcendent truths are not something that we would countenance with respect to ethical claims. Although we accept that ethical truths can be lost on an entire community (as, e.g., the injustice of slavery was in ancient Greece) we do not allow that there could be present ethical truths that we could not possibly know about. And in this respect the same appears to be true of aesthetic truths, and other evaluative matters.

\section{THE PROBLEM OF THE THIRD WAY:}

\section{DEFLATIONARY VS INFLATIONARY METAPHYSICS}

Nonetheless, the present account of Putnam's progress is not the whole story. According to an insightful retrospective survey, Gary Ebbs sees Putnam as primarily in the business of attempting "to clarify our implicit practice-based understanding of these norms" - viz., "norms that determine what we are talking about, when we agree, and when we disagree" - but he makes the following revealing admission,

The view I present... is perhaps incompatible with some of what he has written. $(1992,2)$

Indeed! So, too, the present paper is incompatible with some of what Putnam has written. However, this "some" is not a minor or dispensable aspect of Putnam's work but involves "the realism issue" which has always been at the core of his philosophical concerns. ${ }^{14}$ Although Putnam has been centrally concerned with normative cartography, as we might call it - providing detailed maps of the normative fine-grain of our linguistic practices and plotting the various faces of objectivity from discourse to discourse - he has also repeatedly committed himself to the realist positions that he later rounds on and criticizes.

In other words, Putnam is not happy to consistently practice philosophy in the metaphysically quietist manner of Wittgenstein, who describes the logic of language as part of a constant effort to overcome metaphysical assertion (despite sometimes sounding as if he were content to do that). In retrospect it is clear that Putnam has always had a powerful inclination to answer the big metaphysical

13 Putnam gave Ghandi as an example at a conference honouring his work at University College, Dublin, in 2007.

14 Witness the large number of Putnam's books with the terms "realism" or "reality" in the title. 
questions of philosophy, especially the question, "How does language (or mind) hook up to the world?" even in spite of a recognition of how loaded this (and other metaphysical questions like it) is; and despite an acute awareness of how metaphysical uses of language tend to raise significant problems of coherence and intelligibility.

There is a deep - and, for this reader at least, philosophically fruitful - fault line in Putnam's thinking between a metaphysically deflationary and a metaphysically inflationary conception of the search for a "third way" in the realism debate: 1) metaphysically deflationary: offering a Wittgensteinian diagnosis of the realism issue which does not require one to take sides in this (or any) metaphysical debate nor to propose a moderate "middle" position. Such metaphysical quietism goes hand in hand with providing a more realistic account of the norms of linguistic practice (meaning a more plausible account of how reasonable or competent participants in linguistic practice should reflectively understand themselves) since a key theme of Putnam's is that such norms require no metaphysical foundations; and 2) metaphysically inflationary: providing a moderate metaphysical position that is conceived as located between the two extremes of metaphysical construction (e.g. Metaphysical Realism) and metaphysical destruction (e.g. external world skepticism, relativism) $(1999,18)$.

The metaphysically deflationary mode is centrally concerned with the penetrating normative cartography which has led to many of Putnam's most influential discoveries, e.g., his account of our reference to natural kind terms like gold (1988, ch. 2). Once again, a false metaphysical account of the matter must be cleared away in order to make room for a just and suitably nuanced description of our actual practice. This point has been missed because all too frequently Putnam has been misread as committed to a version of Kripke's substance essentialism. Putnam's actual claim is that, in our scientifically minded culture (one that extends back several centuries at least), the ordinary reference of a natural kind term is interdependent with, and so conditioned by, the scientific community's intention to refer to the natural kind's hidden microstructure (e.g. gold is the element with the atomic number 79). The moral is that it is not metaphysics that tells us how to use our natural kind terms (contra Kripke) but a certain historically situated scientific practice. ${ }^{15}$

15 This may seem a surprizing example since many philosophers assume Putnam follows Kripke in thinking that natural kinds have a metaphysical essence as a matter of metaphysical necessity. Putnam, however, finds such metaphysical notions dubious and of questionable 
But we cannot avoid Putnam's inflationary mode of philosophizing as Ebbs understandably attempts to do. An example is Putnam's late return to a form of metaphysical realism (uncapitalized) (cf. 2012, ch. 2). As we have seen, the account of Putnam as a normative cartographer fits particularly well with common sense realism which is explicitly said to be a non-metaphysical outlook (i.e. neither metaphysical nor anti-metaphysical) whose aim is to defend our ordinary ways of talking about the past, other people, tables and chairs, and so on from metaphysical attack.

Unfortunately, Putnam effectively backslides when he pledges allegiance to a sophisticated form of metaphysical realism which, unlike traditional Metaphysical Realism (capitalized), is compatible with conceptual relativity. ${ }^{16}$ The label "metaphysical realist", Putnam explains,

[applies] to all philosophers who reject verificationism and all talk of our "making" the world $(2012,101)$

For anyone sympathetic to the metaphysically deflationary mode of philosophizing - articulating in detail the complex normative topography of our practices from a participant perspective - this metaphysical pronouncement will seem an unfortunate and retrograde step. Like all forms of metaphysics, metaphysical realism suffers from the problem of dogmatic over-generalization, falling victim to what Wittgenstein called the philosophical "craving for generality" $(1969,18)-$ the wish to explain things in full generality from the armchair.

For a start, Putnam seems to have forgotten that common sense realism was topic-specific and that he accepts something close to verificationism with regard to common sense talk about ordinary perceptible objects as well as about ethical and legal (and, presumably, also aesthetic and political) discourse: for, in such cases,

intelligibility. He remarks, "I could understand [Kripke's notion of individual essences], at best, only by regarding them as linguistic proposals for assigning truth-values to certain counterfactuals in a not implausible way" $(1990,67)$. For the common misreading of Putnam as an essentialist see, e.g., Bird and Tobin (2018).

${ }^{16}$ Arguably one reason why Putnam adopts this metaphysical position is as an over-reaction to the criticism that he has made the "flat-out philosophical mistake" of thinking that "there are no objects independent of conceptual scheme" (Thomasson, 2015, 60) - which is an understandable misinterpretation given that Putnam for a time confused conceptual relativity, where conceptual choice does determine ontology in a limited domain, with conceptual pluralism, the distinct thesis that there are different descriptions of the world (say, in the language of physics, or of common sense objects) no one of which is metaphysically primary. See, e.g., Putnam (1987, lecture 2). 
"truth cannot transcend warranted assertibility under good enough conditions" (2002a, 108). ${ }^{17}$ And, to ward off a possible objection at this point, Putnam certainly accepts that, say, ethical values and the ethical life in which they figure are part of the world that the (sophisticated) metaphysical realist is theorizing about; and the same goes for legal, aesthetic and political values. Putnam could reply that the aim is only to deny the reduction of the concept of truth to that of verification; but if that is all that is going on then there is no reason to think of it as a contribution to metaphysics. It is a conceptual insight!

A similar problem arises for Putnam's blanket rejection of all talk of 'making' the world. What of the urban landscape, the built world of the city, its architecture, parks, roads and bridges? Or all of the many and various artifacts like tables, chairs, coffee cups and pencils? And what of institutional facts such as that two people are married or that writing on a piece of paper under certain conditions counts as voting? Surely all such facts are made by us, causally or constitutively, or both.

In defending his late turn to metaphysical realism Putnam writes,

And if I have long repented of having once said that "the mind and the world make up the mind and the world," that is because what we actually make up is not the world, but language games, concepts, uses, conceptual schemes. To confuse making up the notion of a boson, which is something the scientific community did over time, with making up real quantum mechanical systems is to slide into idealism, it seems to me. And that was a bad thing to slide into. $(2012,76)$

But, as we have just seen, a great deal of the social world we do, in fact, make up so metaphysical realism is either false or misleading! Furthermore, Putnam's acceptance of the criticism of his having said that "the mind and the world make up the mind and the world" as a "slide into idealism" is to forget that when he originally spoke in these terms he was explicitly speaking metaphorically,

My view is not a view in which the mind makes up the world... If one must use metaphorical language, then let the metaphor be this: the mind and the world make up the mind and the world. (1981, xi, emphasis added)

The explicitly metaphorical claim concerning the mind and world's coconstitutive activity is not to be understood as a commitment to a new moderate

${ }^{17}$ In line with the objectivist focus of the current paper Putnam remarks further, "there is no reason to suppose that one cannot be what is called a 'moral realist' in meta-ethics, that is, hold that some 'value judgments' are true as a matter of objective fact, without holding that moral facts are or can be recognition transcendent facts" (2002a, 108). 
metaphysical position in the realism-idealism debate but is a deflationary move aimed at the rejection of both positions - certainly a rejection of the idea that we face a forced choice between them. ${ }^{18}$ Note, too, that in this initial formulation, Putnam explicitly distances himself from any idealist supposition that the mind "makes up" the world as a whole - although it is again incautious and misleading since, for one thing, the vast realm of artefacts is made by our minds.

If there was a slide into idealism along Putnam's path it was in adopting "internal realism" where this involves the wholesale reduction of truth to idealized rational assertibility as follows:

$\mathrm{S}$ is true if and only if believing $\mathrm{S}$ would be justified if epistemic conditions were good enough.

As Putnam later realized, since internal realism took for granted an interface conception of perception, the notion of epistemically "ideal" conditions of justification inevitably collapses into solipsism $(2012,83-4) .{ }^{19}$ Again, the fault lies in Putnam's apparent wish to engage with the traditional metaphysical questions and, despite occasional Wittgensteinian misgivings, to offer definitive - although qualified - answers to them. Putnam arguably should have been content to philosophize in the metaphysically deflationary mode making such correct observations as that we should resist reducing truth to any epistemic notion, and from the point of view of which we are able to acknowledge two key insights of verificationism (even if they require a reinterpretation of that doctrine):

1) "that truth and rational acceptability are interdependent notions" even if there are cases in which truth transcends what we can find out about (1988, 115);

2) "some subject matters [e.g. talk about the furniture in the room, ethics, law] are such that their very nature entails that if the statement in question is true, then the statement can, under certain conditions, be verified" (2002a, 108). The coincidence of truth and rational assertibility in many everyday and evaluative cases does not entail that the concept of truth is reducible to that of rational assertibility.

${ }^{18}$ It is clear that at this time Putnam regarded the realist-idealist debate as incoherent if taken at face value so talk of "choosing" either side is moot.

19 The question he did not face is, how can an internal realist refer to epistemically ideal conditions? 
An insight we can draw from Putnam in his metaphysically deflationary mapping of social normative space and the different kinds and strengths of objectivity it makes available is that the relations between truth and justification (or rational assertibility) are simply too varied and complex across subject matters and situations to be capable of being fruitfully captured in any general doctrine of realism or antirealism. ${ }^{20}$

\author{
David Macarthur \\ University of Sydney \\ david.macarthur@sydney.edu.au
}

\title{
BIBLIOGRAPHY
}

Bird, A. \& TOBIN, E. (2018): “Natural Kinds”, The StanfordEncyclopedia of Pbilosophy. Edward N. Zalta (ed.), https://plato.stanford.edu/archives/spr2018/entries/natural-kinds/.

De Gaynesford, M. (2006): Hilary Putnam, Durham: Acumen.

EBBS, G. (1992): "Realism and Rational Inquiry,” Hill, C. (ed.) (1993), pp. 1-33.

Hill, C. (ed.) (1992): “The Philosophy of Hilary Putnam,” Pbilosopbical Topics, vol. 20 no. 1. HORWICH, P. (2005): Reflections on Meaning. Oxford: Oxford University Press.

Macarthur, D. (2014): "What's the Use? Price \& Wittgenstein on Naturalistic Explanations of Language." Al-Mukhatabat Journal: Special issue on Wittgenstein, No. 9: 77-95.

NAGEL, T. (1986): The View from Nowhere. Oxford: Oxford University Press.

PriCe, H. (2011): Naturalism without Mirrors. Oxford: Oxford University Press.

Putnam, H. (1978): Meaning and the Moral Sciences. London: Routledge.

Putnam, H. (1987): The Many Faces of Realism. La Salle, IL.: Open Court.

Putnam, H. (1988): Representation and Reality. Cambridge, MA: MIT Press.

Putnam, H. (1990): Realism with a Human Face. Conant, J. (ed.) Cambridge, MA: Harvard University Press.

Putnam, H. (1995): "Pragmatism," The Proceedings of the Aristotelian Society, vol. 95, pp. 291-306.

PutnAm, H. (1998): “Kripkean Realism and Wittgenstein's Realism,” Biletzki, A. \& Matar, A. (eds.) The Story of Analytic Pbilosophy: Plots and Heroes. New York: Routledge, 241-252.

Putnam, H. (1999): The Threefold Cord: Mind, Body and World. New York: Columbia University Press.

Putnam, H. (2002a): Collapse of the Fact/Value Dichotomy and Other Essays. Cambridge, MA: Harvard University Press.

${ }^{20}$ Here I fully endorse Ebbs's conclusion, “There is no reason to think that there are any informative generalizations about the relationship of [our concepts of truth and rational acceptability]" (1992, 26). 
Putnam, H. (2002b): "Pragmatism and Nonscientific Knowledge." Hilary Putnam: Pragmatism and Realism, Conant, J. \& Żegleń, U. (eds.) New York: Routledge, 14-24.

Putnam, H. (2004): Ethics without Ontology. Cambridge, MA: Harvard University Press.

Putnam, H. (2012): Philosophy in an Age of Science: Physics, Mathematics and Skepticism. De Caro, M. \& Macarthur, D. (eds.). Cambridge, MA: Harvard University Press.

RaWLs, J. (1993): Political Liberalism. New York: Columbia University Press.

Thomasson, A. (2015): Ontology Made Easy. Oxford: Oxford University Press.

Williams, B. (1985): Ethics and the Limits of Philosophy. London: Fontana.

Wittgenstein, L. (1969): The Blue \& Brown Books, 2 ${ }^{\text {nd }}$ ed. G.E.M. Anscombe and G.H. von Wright. Oxford: Blackwell.

WiTTGenstein, L. (1972): On Certainty. G.E.M. Anscombe and G.H. von Wright. Oxford: Blackwell. 